\title{
Hypothalamic-pituitary-adrenal axis activation and immune regulation in heat-stressed sheep after supplementation with polyunsaturated fatty acids
}

\author{
M. Caroprese, ${ }^{* 1}$ M. G. Ciliberti, ${ }^{*}$ G. Annicchiarico, $†$ M. Albenzio, ${ }^{*}$ A. Muscio, ${ }^{*}$ and A. Sevi ${ }^{*}$ \\ *Department of the Sciences of Agriculture, Food and Environment (SAFE), University of Foggia, Via Napoli, 25, 71122 Foggia, Italy \\ †Council for Research and Experimentation in Agriculture, 71020 Foggia, Italy
}

\begin{abstract}
The aim of this study was to assess the effects of supplementation with polyunsaturated fatty acids from different sources on immune regulation and hypothalamic-pituitary-adrenal (HPA) axis activation in heatstressed sheep. The experiment was carried out during the summer 2012. Thirty-two Comisana ewes were divided into 4 groups (8 sheep/group): (1) supplemented with whole flaxseed (FS); (2) supplemented with Ascophyllum nodosum (AG); (3) supplemented with a combination of flaxseed and A. nodosum (FS+AG); and (4) control (C; no supplementation). On d 22 of the experiment, cortisol concentrations in sheep blood were measured after an injection of ACTH. Cellular immune response was evaluated by intradermic injection of phytohemagglutinin (PHA) at 0,15 , and $30 \mathrm{~d}$ of the trial. Humoral response to ovalbumin (OVA) was measured at 0,15 , and $30 \mathrm{~d}$. At 0,15 , and $30 \mathrm{~d}$ of the experiment, blood samples were collected from each ewe to determine production of T-helper (Th) 1 cytokines (IL12 and IFN- $\gamma$ ), and Th2 cytokines (IL-10, IL-4, IL-13), and concentrations of heat shock proteins (HSP) 70 and 90. Ewes supplemented with flaxseed alone had greater cortisol concentrations and a longer-lasting cell-mediated immune response compared with ewes in the control and other groups. Anti-OVA IgG concentrations increased in all groups throughout the trial, even though ewes in the FS+AG group had the lowest antiOVA IgG concentrations at $15 \mathrm{~d}$. The level of IL-10 increased in all groups throughout the experiment; the FS+AG group had the lowest IL-13 concentration at 15 and $30 \mathrm{~d}$. The concentration of HSP 70 increased in AG ewes at the end of the experiment and decreased in FS ewes, whereas that of HSP 90 increased in FS ewes compared with FS+AG ewes. Flaxseed supplementation was found to influence in vivo HPA activation in heat-stressed sheep, resulting in increased cortisol
\end{abstract}

Received November 8, 2013.

Accepted March 16, 2014.

${ }^{1}$ Corresponding author: mariangela.caroprese@unifg.it concentrations, probably to meet increased energy demand for thermoregulation. Flaxseed supplementation also supported Th1 response via a complex cross-talk between IL-10, IL-12, and IFN- $\gamma$ production.

Key words: cytokine, sheep, polyunsaturated fatty acids, heat stress, immune regulation

\section{INTRODUCTION}

Stressors of different natures and intensity can induce production of extracellular and intracellular mediators to modulate cell responses. Heat stress stimulates signal transduction pathways to alter gene expression of immune cell mediators (i.e., cytokines) and can activate heat shock response. Heat shock response evokes large changes in the secretion and activity of heat shock proteins (HSP), which are strictly connected to the endocrine and immune system (Collier et al., 2008). The HSP are classified into different families according to their molecular weights; those of approximately 90, 70, and $27 \mathrm{kDa}$ are referred to as HSP 90, HSP 70, and HSP 27 , respectively. Cultured sheep lymphocytes have been demonstrated to produce HSP 90 and HSP 70 in response to thermal stress (Guerriero and Raynes, 1990). The engagement of extracellular HSP also includes the promotion of cytokine activity (Martin et al., 2009). Distinct cytokine patterns are responsible for the effector functions and development of T-helper 1 (Th1) and T-helper 2 (Th2) cell responses. The Th1 cells activate cellular immunity and inflammatory responses, whereas the Th2 cells control humoral immunity and promote antiinflammatory responses. The ability of animals to produce selectively Th1 cytokines (IFN- $\gamma$ and IL-12) and Th2 cytokines (IL-10, IL-4, IL-13), and thereby to regulate the Th1:Th2 cytokine balance, is highly temperature dependent (Park et al., 2005). Hyperthermia can downregulate Th1 cytokines in favor of the secretion of Th2 cytokines, thus suppressing cell-mediated immunity (Murzenok et al., 1997; Elenkov and Chrousos, 1999; Webster et al., 2002). Ewes subjected to heat stress showed impairment of their cellular immune 
response after an intradermal injection of mitogens and had increased cortisol concentrations (Sevi et al., 2002; Caroprese et al., 2012). It has been demonstrated that corticosteroids, which can increase under stress conditions, bind to DNA and inhibit the expression of genes involved in T-cell activation and cytokine production (Sgorlon et al., 2012). Antiinflammatory properties of corticosteroids lead to decreased phagocytic cell activity, which in turn alters lymphocyte function (Ronsen at al., 2001). Several ruminant diseases, including Johne's disease, require a strong cell-mediated immune response to protect against pathogenic bacteria (Begg et al., 2005). Therefore, the maintenance of the proper Th1:Th2 balance could be a critical factor in facing immunological challenges, particularly if they occur during the summer season.

Few studies have focused on the effects of heat stress on nutrient utilization and circulating hormones to cope with immune challenges in sheep. Recently, Caroprese et al. (2012) found that in heat-stressed ewes, the supplementation of whole flaxseed, rich in the n-3 PUFA $\alpha$-linolenic acid (C18:3, ALA), sustains humoral responses and induces an increase in cortisol secretion. The precise mechanisms underlying cellular immune and humoral functions in sheep under high temperatures, however, remain undefined, particularly with regard to cytokine profiles in vivo and to activation of the hypothalamic-pituitary-adrenal (HPA) axis.

To overcome heat stress in lambs, Saker et al. (2004) suggested supplementation with an extract from a brown seaweed, Ascophyllum nodosum (Tasco; Acadian Seaplants Ltd., Dartmouth, NS, Canada). The high antioxidant content of $A$. nodosum was found to be partly responsible for the enhanced immune function and antioxidant status in heat-stressed lambs. In addition, A. nodosum contains n-3 PUFA such as eicosapentaenoic acid (C20:5, EPA), which are considered health-promoting molecules, and fucoidan, which has antiinflammatory and antimicrobial activities.

No studies have evaluated the combined effect of flaxseed and algae as supplementation to heat-stressed sheep. We hypothesized that the administration of PUFA supplemented as whole flaxseed or algae, or in combination, to the diets of dairy sheep under heat stress could contribute to alter HPA activation and sustain their immune functions and Th1:Th2 balance.

The objective of the present experiment was therefore to determine the effects of supplementing the diet with PUFA from flaxseed or algae, or their combination, on immune regulation, in terms of cell-mediated and humoral immune responses and HPA activation in sheep under heat-stress conditions. We also investigated the balance between Th1 and Th2 cells by monitoring secretion of interleukins and production of HSP in vivo.

\section{MATERIALS AND METHODS}

\section{Animals and Experimental Design}

The experiment lasted $30 \mathrm{~d}$ and was conducted during the summer (June-July) 2012 at Segezia research station of the Council for Research and Experimentation in Agriculture (CRA-ZOE) in Apulia, Italy. Thirty-two late-lactation Comisana ewes $(202.1 \pm 5.3 \mathrm{~d}$ of lactation, mean $\pm \mathrm{SD}$ ) were divided into 4 groups of 8 balanced for milk yield, BW, and BCS. Groups were separately reared in external pens of $5 \times 12 \mathrm{~m}$ bounded with a mesh fence; the trough and crib were located in the external areas. During the trial, ambient temperature and relative humidity in indoor and outdoor areas were monitored with thermo-hygrographs (I-20090, LSI, Settala Premenugo-Milano, Italy) placed at 1.5 $\mathrm{m}$ from the floor. The average temperature-humidity index (THI) was calculated using the formula of Kelly and Bond (1971).

All groups were individually fed twice daily and received $1.8 \mathrm{~kg} /$ ewe daily of oat hay. The control group also received $1 \mathrm{~kg}$ /ewe daily of pelleted concentrate (Mangimificio Molino Gallo, Potenza, Italy), whereas ewes in the experimental groups were supplemented with whole flaxseed (FS; Lin Tech, Tecnozoo srl, Torreselle di Piombino Dese, Italy), or A. nodosum (AG; Tasco), or their combination (FS+AG). Thus, ewes in the FS group received $750 \mathrm{~g}$ /ewe per day of pelleted concentrate, and $250 \mathrm{~g} /$ ewe per day of whole flaxseed; ewes in the AG group received $1 \mathrm{~kg} /$ ewe per day of pelleted concentrate in which $5 \%$ A. nodosum was incorporated; ewes in the FS+AG group were supplemented with both flaxseed $(250 \mathrm{~g} / \mathrm{d})$ and pelleted concentrate (750 g/d) incorporating 5\% A. nodosum. Dry matter intake was determined for each experimental group by weighing the refusals at $0800,1200,1600$, and 2000 h. Water was available ad libitum for all groups from automatic drinking troughs at any time of day.

All procedures were conducted according to the guidelines of EU Directive 2010/63/EU (European Union, 2010) on the protection of animals used for experimental and other scientific purposes. Ewes were healthy and their conditions were carefully examined by veterinarians throughout the trial to exclude the presence of signs of diseases.

The chemical composition of diets was carried out by standard procedures (AOAC, 1990). Ingredients and chemical composition of diets are reported in Table 1. The determination of methyl esters of the diet ingredients was carried out according to O'Fallon et al. (2007). Briefly, $1 \mathrm{~g}$ of each sample was pipetted into a screw-cap $(16 \times 25 \mathrm{~mm})$ reaction tube. Into each tube, $1.0 \mathrm{~mL}$ of the C13:0 internal standard $(0.5 \mathrm{mg}$ of $\mathrm{C} 13: 0 / \mathrm{mL}$ of methanol), $0.7 \mathrm{~mL}$ of $\mathrm{KOH}$, and $5.3 \mathrm{~mL}$ 
of methanol were added during incubation at $55^{\circ} \mathrm{C}$ for $1.5 \mathrm{~h}$, and the tubes were inverted to mix for $5 \mathrm{~s}$ every 20 min. After cooling the tubes in a cold water bath, $3 \mathrm{~mL}$ of hexane was added to each tube and mixed by vortex for $5 \mathrm{~min}$. The tubes were centrifuged at room temperature for $5 \mathrm{~min}$ at $500 \times g$; then, $1 \mathrm{~mL}$ of supernatant was taken from each tube, transferred into vials, and stored at $-20^{\circ} \mathrm{C}$ for analysis by GC. Fatty acid profiles were quantified using a GC $(6890 \mathrm{~N}$; Agilent Technologies, Santa Clara, CA) equipped with a flame-ionization detector. Helium was the carrier gas, the gas flow rate was $0.8 \mathrm{~mL} / \mathrm{min}$, and the column head pressure was $175 \mathrm{kPa}$. The oven temperature (Eulitz et al., 1999) was initially held at $70^{\circ} \mathrm{C}$ for 4 min, and then programmed to increase at $13^{\circ} \mathrm{C} / \mathrm{min}$ to $175^{\circ} \mathrm{C}$ and then held isothermally for $45 \mathrm{~min}$. The column used was a capillary column (HP88; $100 \mathrm{~m} \times$ $0.24 \mathrm{~mm}$ i.d., $0.20-\mu \mathrm{m}$ film thickness, Agilent Technologies). Concentrations of FAME were analyzed utilizing a calibration curve with a mixture of standards of 50 FA (GLC Reference standard 674, Nu-Chek Prep Inc., Elysian, MN) with added CLA standards: C18:2 trans8,cis-10; C18:2 cis-9,trans-11; C18:2 cis-11,trans-13; C18:2 trans-9,cis-11; C18:2 cis-8,cis-10; C18:2 cis9,cis-11; C18:2 trans-10,cis-12; C18:2 trans-8,trans-10; C18:2 trans- 9 ,trans- 11 ; C18:2 trans-10,trans- 12 ; C18:2 trans-11,trans-13 (GLC Reference standard UC-59M, $\mathrm{Nu}$-Chek Prep Inc.).

Flaxseed FA composition was mainly characterized by $53.21 \mathrm{~g} / 100 \mathrm{~g}$ of total FA of C18:3n-3 (ALA), whereas $A$. nodosum was characterized by $37.03 \mathrm{~g} / 100$ $\mathrm{g}$ of FA of C18:1 cis-9 and by $5.03 \mathrm{~g} / 100 \mathrm{~g}$ of FA of C20:5n-3 (EPA).

\section{BCS and Respiration Rate}

At the beginning of the experiment and then weekly, the BCS of the ewes was measured in the morning after milking and before feeding time and recorded using a 6 -point scale $(0=$ thin, $5=$ fat $)$. Respiration rate $(\mathbf{R R})$ was measured in all animals weekly at $1430 \mathrm{~h}$ by counting the rate of flank movements each $30 \mathrm{~s}$ (Caroprese et al., 2012).

\section{Plasma Cortisol Determination}

On d 22 of the experiment, plasma cortisol concentrations were measured; as demonstrated in a previous study, the effects of a diet based on flaxseed supplementation were evident after at least $20 \mathrm{~d}$ from the beginning of the treatment (Caroprese et al., 2011). The ewes were intravenously injected with $2 \mathrm{IU}$ of $\mathrm{ACTH} /$ $\mathrm{kg}$ of $\mathrm{BW}^{0.75}$ (Sigma Aldrich, Milan, Italy). Blood samples $(7 \mathrm{~mL})$ for evaluation of cortisol concentrations were collected in heparinized vacuum tubes (Becton Dickinson, Plymouth, UK) from the jugular vein immediately before and 60, 120, and 240 min after ACTH injection. Hormone concentration was determined by a competitive enzyme immunoassay (Cortisolo EIA WELL KS18EW, Radim, Rome, Italy), according to Caroprese et al. (2012).

\section{In Vivo Cell-Mediated Immunity}

At the beginning of the experiment and on $\mathrm{d} 15$ and 30 of the trial, a skin test was performed to induce nonspecific delayed-type hypersensitivity by intradermic

Table 1. Ingredients and chemical composition (\% of DM unless otherwise noted) of the diets

\begin{tabular}{|c|c|c|c|c|}
\hline \multirow[b]{2}{*}{ Item } & \multicolumn{4}{|c|}{ Diet } \\
\hline & Control & $\mathrm{AG}$ & FS & $\mathrm{FS}+\mathrm{AG}$ \\
\hline Oat hay & 64.50 & 64.39 & 64.37 & 64.38 \\
\hline Concentrate $^{1}$ & 35.50 & 17.72 & 26.57 & 8.86 \\
\hline $5 \%$ Ascophyllum nodosum concentrate (AG) & 0 & 17.89 & 0 & 17.70 \\
\hline Whole flaxseed $^{2}(\mathrm{WF})$ & 0 & 0 & 9.06 & 9.06 \\
\hline Ether extract & 1.93 & 2.04 & 5.02 & 5.12 \\
\hline $\mathrm{CP}$ & 12.53 & 12.84 & 12.89 & 13.20 \\
\hline $\mathrm{ADF}$ & 27.75 & 28.03 & 28.48 & 28.76 \\
\hline $\mathrm{NDF}$ & 53.36 & 53.32 & 54.58 & 54.55 \\
\hline $\mathrm{ADL}$ & 3.44 & 3.56 & 3.83 & 3.96 \\
\hline $\mathrm{NE}_{\mathrm{L}},{ }^{3} \mathrm{Mcal} / \mathrm{kg}$ & 1.30 & 1.31 & 1.29 & 1.30 \\
\hline
\end{tabular}

${ }^{1}$ Contained corn meal, soybean meal, wheat germ meal, wheat meal, roasted soybean seeds, barley meal, wheat fine bran, corn cracked, sugarcane molasses, partially debarked sunflower meal, bentonite, dried pulp, calcium carbonate, sodium bicarbonate, sodium chloride, magnesium oxide, $8.3 \mathrm{IU} / \mathrm{g}$ of vitamin $\mathrm{A}, 8.2 \mathrm{IU} / \mathrm{g}$ of vitamin $\mathrm{D}_{3}, 99 \mathrm{mg} / \mathrm{kg}$ of vitamin $\mathrm{E}, 0.07 \mathrm{mg} / \mathrm{kg}$ of vitamin $\mathrm{B}_{1}, 255 \mathrm{mg} / \mathrm{kg}$ of vitamin PP, $488 \mathrm{mg} / \mathrm{kg}$ of Cl, $293 \mathrm{mg} / \mathrm{kg}$ of $\mathrm{Fe}, 1.26 \mathrm{mg} / \mathrm{kg}$ of $\mathrm{Co}, 1 \mathrm{mg} / \mathrm{kg}$ of $\mathrm{Cu}$, and $0.4 \% \mathrm{Na}$.

${ }^{2}$ Lin Tech (Tecnozoo srl, Torrreselle di Piombino Dese, Italy).

${ }^{3}$ Calculated according to NRC (2001). 
injection of $1 \mathrm{mg} / \mathrm{mL}$ of phytohemagglutinin (PHA) (Sigma Aldrich) dissolved in sterile saline solution. At each sampling time, the injection was administered into the center of a 2-cm-diameter circle marked on shaved skin on the upper side of each shoulder. The determination of lymphocyte proliferation, measured as skinfold thickness, was calculated from the 2 measurements made with calipers as the difference between 24-h postinjection thickness and preinjection thickness.

\section{Humoral Immune Response}

To evaluate the humoral response to ovalbumin (OVA, chicken egg albumin), and to measure anti-OVA IgG concentrations, ewes were subjected on $\mathrm{d} 0$ to a subcutaneous injection of $6 \mathrm{mg}$ of OVA (Sigma Aldrich) dissolved in $1 \mathrm{~mL}$ of sterile saline solution and $1 \mathrm{~mL}$ of incomplete Freund's adjuvant (Sigma Aldrich). A second injection without adjuvant was repeated $7 \mathrm{~d}$ later. Antibody titers were determined in blood samples collected in heparinized vacuum tubes (Becton Dickinson) immediately before the first antigen injection $(0 \mathrm{~d})$ and then at 15 and $30 \mathrm{~d}$ of the study period. An ELISA was performed in 96-well, U-bottomed microtiter plates. Wells were coated with $100 \mu \mathrm{L}$ of antigen (10 mg of OVA/ $\mathrm{mL}$ of PBS) at $4^{\circ} \mathrm{C}$ for $12 \mathrm{~h}$, washed with PBS ( $\left.\mathrm{pH} 7.2\right)$ and $0.05 \%$ Tween 20 (PBST), incubated with $1 \%$ skim milk at $37^{\circ} \mathrm{C}$ for $1 \mathrm{~h}$ to reduce nonspecific binding, and then washed. The sheep serum (1:5,000 dilution in PBS) was added and incubated at $37^{\circ} \mathrm{C}$ for $1 \mathrm{~h}$. The extent of antibody binding was detected using a horseradish peroxidase-conjugated donkey anti-sheep IgG (Sigma Aldrich; 1:20,000 dilution in PBS). After washing, 100 $\mu \mathrm{L}$ of substrate $\left(1 \mathrm{mg}\right.$ of $3,3^{\prime} 5,5^{\prime}$-tetramethylbenzidine (TMB), $1 \mathrm{~mL}$ of dimethylsulfoxide, $9 \mathrm{~mL}$ of phosphatecitrate buffer, and $2 \mu \mathrm{L}$ of $\mathrm{H}_{2} \mathrm{O}_{2}$ ) were added to each well. The reaction was completed by adding $50 \mu \mathrm{L}$ of $\mathrm{H}_{2} \mathrm{SO}_{4}$ after $30 \mathrm{~min}$. Optical density was measured at a wavelength of $450 \mathrm{~nm}$ using a titer-ELISA spectrophotometer (Power Wave XS, Biotek, Potton, UK).

Anti-Ova IgG evaluation was a quantitative assay based on a standard curve: $\mathrm{y}=(0.0043-0.919) /[1+$ $\left.(\mathrm{x} / 233)^{1.06}\right]+0.919\left(\mathrm{R}^{2}>99 \%\right)$ made up by ovine $\operatorname{IgG}$ dilutions (A5295, Sigma Aldrich); all plasma samples were read against the curve. Data were expressed as milligrams of anti-OVA IgG per milliliter. The assay was optimized in our laboratory for concentrations of coating antigen, serum, and antibody.

\section{Determination of Cytokines in Plasma Samples by ELISA}

The determination of IL-10 and IL-12 in plasma was carried out by an ELISA according to Kwong et al.
(2002), and Hope et al. (2002), respectively, on blood samples collected on d 0,15 , and 30 of the experiment. Plates were read by a titer-ELISA spectrophotometer (Power Wave XS, Biotek). The intra- and interassay coefficients of variation were 3.2 and $9.8 \%$, respectively, for IL-10, and 5.4 and 10.3\%, respectively, for IL-12.

The levels of IL-13, IL-4, and IFN- $\gamma$ in plasma were assayed by an ELISA: 96-well plates (Sterilin, Cambridge, UK), were coated overnight at $4^{\circ} \mathrm{C}$ with 100 $\mu \mathrm{L}$ of anti-bovine IL-13 (Kingfisher Biotech, St. Paul, MN), anti-bovine IL-4 (AbD Serotec, Kidlington, UK), and anti-bovine IFN- $\gamma$ (AbD Serotec) antibodies in PBS $(2 \mu \mathrm{g} / \mathrm{mL})$. After washing with PBST, the antibody was blocked with PBS-1\% BSA for $1 \mathrm{~h}$. Interleukin-13, IL-4, and IFN- $\gamma$ standard and samples were added to plates for $1 \mathrm{~h}$ at room temperature and afterwards the plates were washed 4 times. Biotinylated secondary anti-bovine IL-13 (Kingfisher Biotech), IL-4 (AbD Serotec), and IFN- $\gamma$ (AbD Serotec) antibodies in PBS $(0.5 \mu \mathrm{g} / \mathrm{mL})$ were added for $1 \mathrm{~h}$, followed by 100 $\mu \mathrm{L}$ of streptavidin-horseradish peroxidase (AbD Serotec). After washing, $100 \mu \mathrm{L}$ of TMB substrate solution was added to each well for $30 \mathrm{~min}$; then, $50 \mu \mathrm{L}$ of 4 $M \mathrm{H}_{2} \mathrm{SO}_{4}$ was added to each well to stop the reaction. The levels of IL-13, IL-4, and IFN- $\gamma$ were measured colorimetrically at $450 \mathrm{~nm}$ (and the absorbance at 540 $\mathrm{nm}$ was subtracted from the absorbance at $450 \mathrm{~nm}$ ) and quantified by interpolation from a standard curve. Data were expressed as micrograms per milliliter of IL13, as nanograms per milliliter of IL-4, and pictograms per milliliter of IFN- $\gamma$. The intra- and interassay CV were 8.8 and $6.1 \%$, respectively, for IL-13, 5.4 and $9.3 \%$, respectively, for IL-4, and 3.9 and $2.3 \%$, respectively, for IFN- $\gamma$.

\section{Determination of HSP in White Blood Cell Lysate}

At 0,15 , and $30 \mathrm{~d}$ of the experiment, white cells from blood were collected after lysis of red cells, as follows: $1 \mathrm{~mL}$ of blood was added to $5 \mathrm{~mL}$ of $0.2 \% \mathrm{NaCl}$ and incubated at $4^{\circ} \mathrm{C}$ for 30 min with mixing by gentle inversion; then, samples were centrifuged at $1,500 \times g$ for $15 \mathrm{~min}$ at $4^{\circ} \mathrm{C}$. After complete removal of supernatant, the pellet was stored at $-20^{\circ} \mathrm{C}$.

Pelleted white cells were lysed with cold radioimmunoprecipitation assay (RIPA) buffer (Thermo Scientific, Waltham, MA), which was implemented with Halt Protease and Phosphatase Inhibitor Cocktail (Thermo Scientific) according to the manufacturer's instructions. The supernatants were collected for determination of HSP.

The concentrations of HSP 70 and HSP 90 in lysate of white blood cells were determined using Sheep Heat Shock Protein 70 (CSB-EQ027551SH, CusabioBiotech 
Co. Ltd., Wuhan, China) and Sheep Heat Shock Protein 90 kits (E14H0304, Blue Gene, Shanghai, China) according to the manufacturers' instructions. Data were expressed in nanograms per milliliter of HSP 70 calculated in $10^{6}$ cells $/ \mathrm{mL}$ of white blood cell lysate and picograms per milliliter of HSP 90 calculated in $10^{6}$ cells $/ \mathrm{mL}$ of white blood cell lysate.

\section{Statistical Analysis}

All variables were tested for normality using the Shapiro-Wilk test (Shapiro and Wilk, 1965). All data were analyzed using ANOVA for mixed models, with animal as a random factor nested in treatment. Data collected during the experiment were analyzed with diet, time of sampling, and their interactions as fixed effects. Data were grouped as variables exhibiting covariance based on initial values. For DMI, weights of refusals taken at 4-h intervals during the day were used as a random factor nested in treatment. When significant effects were found $(P<0.05$, unless otherwise noted), the least significant difference test was used to locate significant differences between means.

\section{RESULTS}

\section{Meteorological Data}

On average, maximum temperature was approximately $38^{\circ} \mathrm{C}$ throughout the study period, and average minimum night temperature was of about $21^{\circ} \mathrm{C}$. Maximum THI was $>86$ during the first day of the experiment, both outside and inside the experimental pens (Figure 1), and THI $>80$ were registered outside the pens during d 9 to 12 and on d 30 of the experiment. Inside the experimental pens, THI $>80$ were registered during d 12 to 14 , d 17 to 19 , and d 20 to 22 of the experiment.

\section{$D M I, B C S$, and $R R$}

Daily DMI are reported in Figure 2: ewes in the AG and $\mathrm{C}$ groups almost entirely consumed their ration, whereas ewes in FS and FS+AG groups had lower DMI $(P<0.01)$. Data related to sheep BCS and RR at the beginning and end of the experiments are reported in Table 2; BCS was affected by time $(P<0.001)$ because in all groups BCS decreased from the beginning of the experiment until wk 3 and then returned to initial levels. Respiration rate was affected by time $(P<0.001)$ and the interaction time $\times \operatorname{diet}(P<0.001)$; lower $\mathrm{RR}$ were measured at $30 \mathrm{~d}$ in FS and FS+AG sheep than in $\mathrm{C}$ and $\mathrm{AG}$ sheep.

\section{Plasma Cortisol}

Cortisol concentrations in plasma peaked at $60 \mathrm{~min}$, decreased at $120 \mathrm{~min}$, and returned to basal concentra-

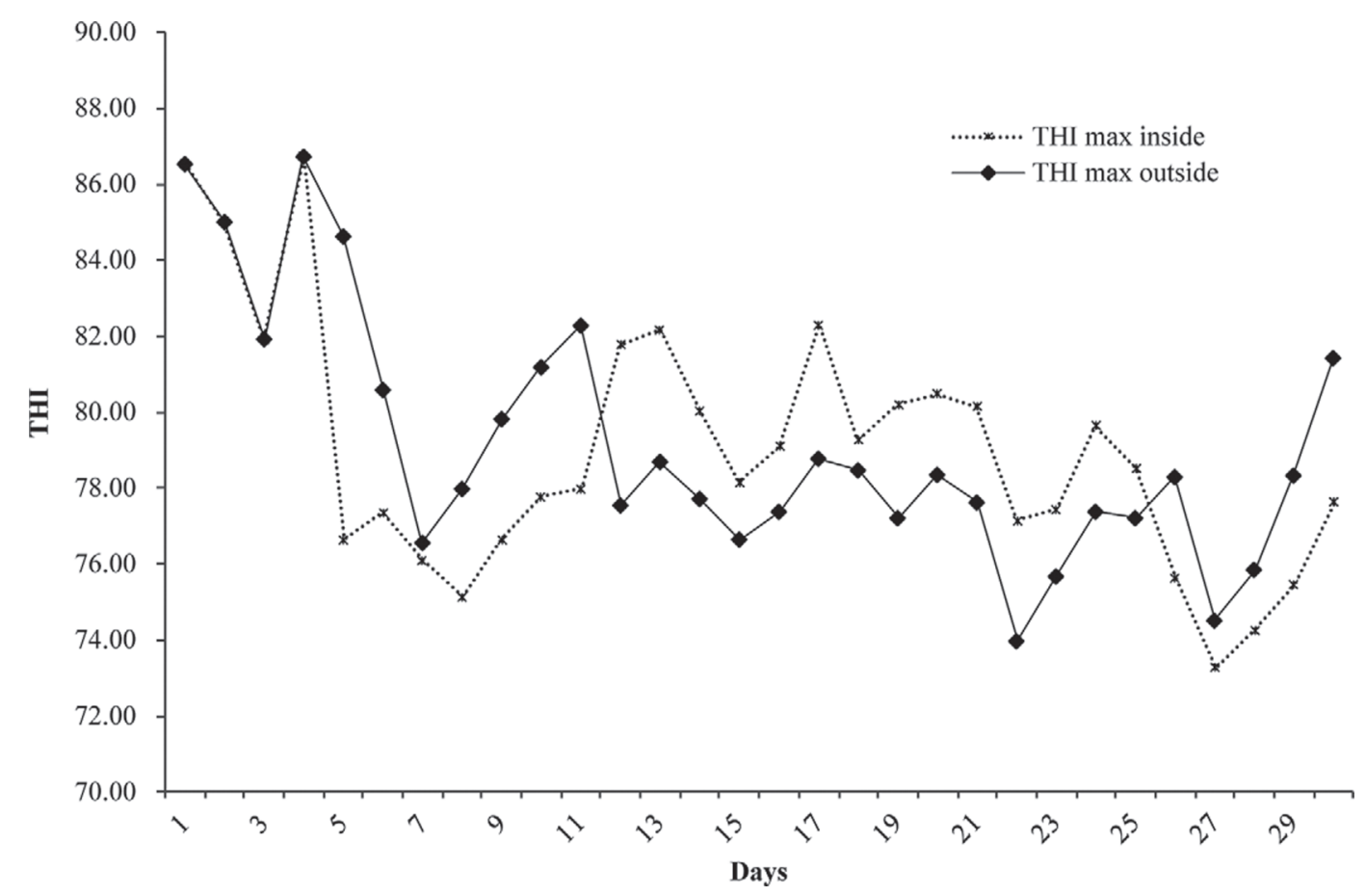

Figure 1. Daily averages of maximum temperature-humidity index (THI) values detected inside and outside the experimental pens during the days of the experimental period. 
Table 2. Least squares means \pm SEM of BCS and respiration rate of sheep fed control diet (C), or supplemented with Ascophyllum nodosum (AG), flaxseed (FS), and a combination of A. nodosum and flaxseed (FS+AG)

\begin{tabular}{|c|c|c|c|c|c|c|c|c|c|}
\hline \multirow[b]{2}{*}{ Item } & \multirow[b]{2}{*}{ Time } & \multicolumn{4}{|c|}{ Treatment } & \multirow[b]{2}{*}{ SEM } & \multicolumn{3}{|c|}{ Effect, $P$-value } \\
\hline & & $\mathrm{C}$ & AG & FS & $\mathrm{FS}+\mathrm{AG}$ & & Diet & Time & $\begin{array}{c}\text { Diet } \times \\
\text { Time }\end{array}$ \\
\hline \multirow[t]{2}{*}{ Respiration rate, breaths/min } & $0 \mathrm{~d}$ & 120.35 & $\begin{array}{r}2.00 \\
130.39\end{array}$ & 128.71 & 129.55 & 0.01 & NS & & ND \\
\hline & $30 \mathrm{~d}$ & $160.35^{\mathrm{a}}$ & $171.39^{\mathrm{a}}$ & $128.71^{\mathrm{b}}$ & $133.55^{\mathrm{b}}$ & 7.64 & NS & $* * *$ & $* * *$ \\
\hline
\end{tabular}

${ }^{\mathrm{a}, \mathrm{b}}$ Means within a row followed by different letters are significantly different at $P<0.05$.

$* * * P<0.001$.

tions 240 min after ACTH challenge in all groups $(P$ $<0.001$; Figure 3). An interaction of time $\times$ diet was found: at 60 min after ACTH challenge, FS ewes displayed greater cortisol concentrations in plasma than did AG, FS+AG, and $\mathrm{C}$ ewes $(P<0.05)$.

\section{In Vivo Cell-Mediated Immunity and Humoral Immune Response}

Cell-mediated immune response of sheep was affected by time of sampling $(P<0.001)$; from the beginning to the end of the trial a reduction of skinfold thickness was found in each group, except for the FS group, in which the skinfold thickness remained unchanged throughout the trial (Figure 4a). Production of anti-OVA IgG was affected by time and the interaction of time $\times \operatorname{diet}(P$ $<0.001$ and $P<0.05$, respectively). The anti-OVA IgG increased in all groups at the end of the experiment. At $15 \mathrm{~d}, \mathrm{FS}+\mathrm{AG}$ ewes had lower anti-OVA IgG titers than $\mathrm{AG}$ and $\mathrm{C}$ ewes (Figure $4 \mathrm{~b}$ ).

\section{Plasma Cytokines}

Concentrations of IL-10 in plasma increased from the beginning to the end of the experimental period, and then increased in all groups $(P<0.001$; Figure 5a). At

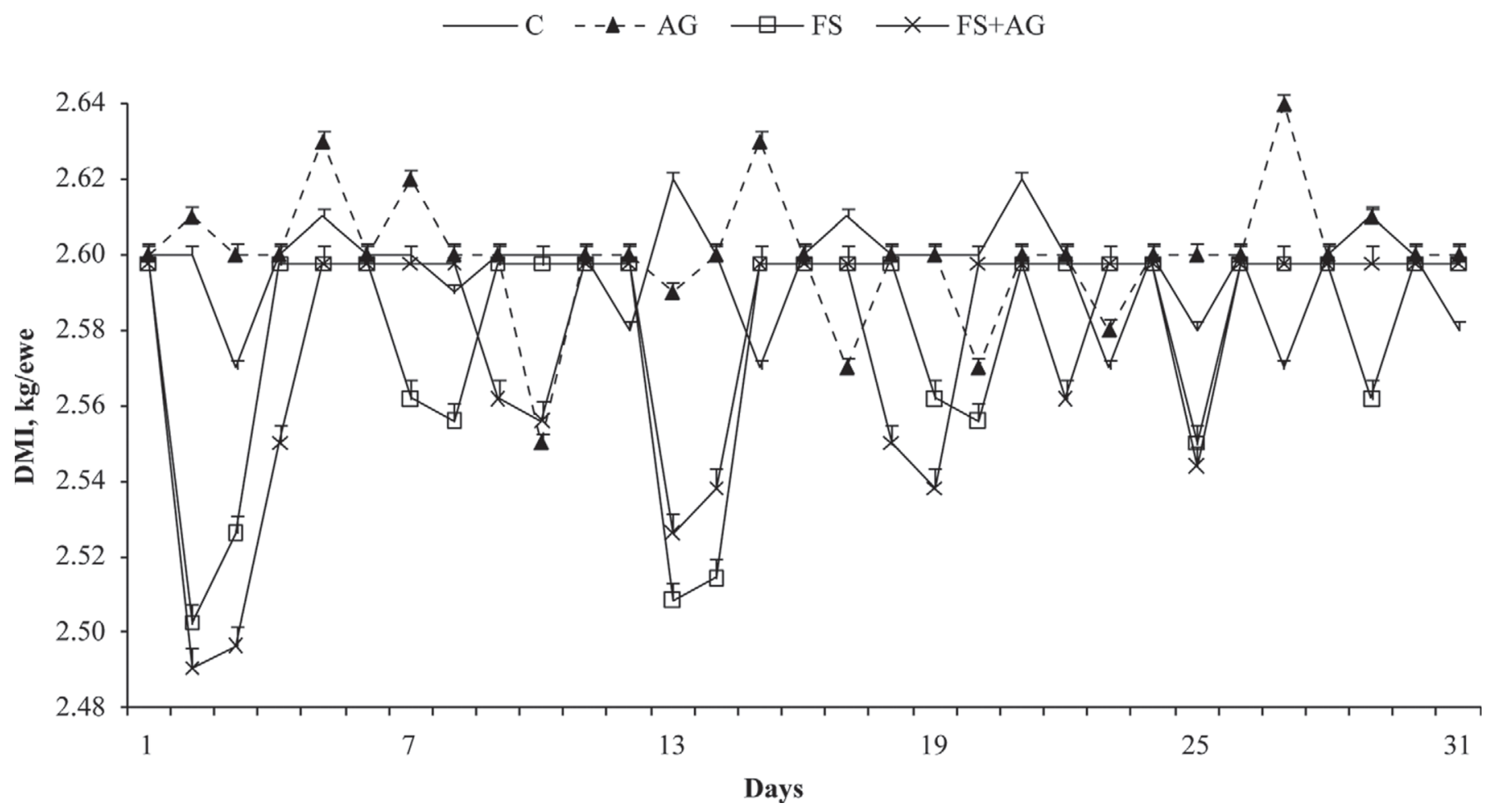

Figure 2. Daily DMI ( \pm SEM) measured in sheep fed control diet (C), or supplemented with Ascophyllum nodosum (AG), flaxseed (FS), or a combination of $A$. nodosum and flaxseed (FS+AG). 


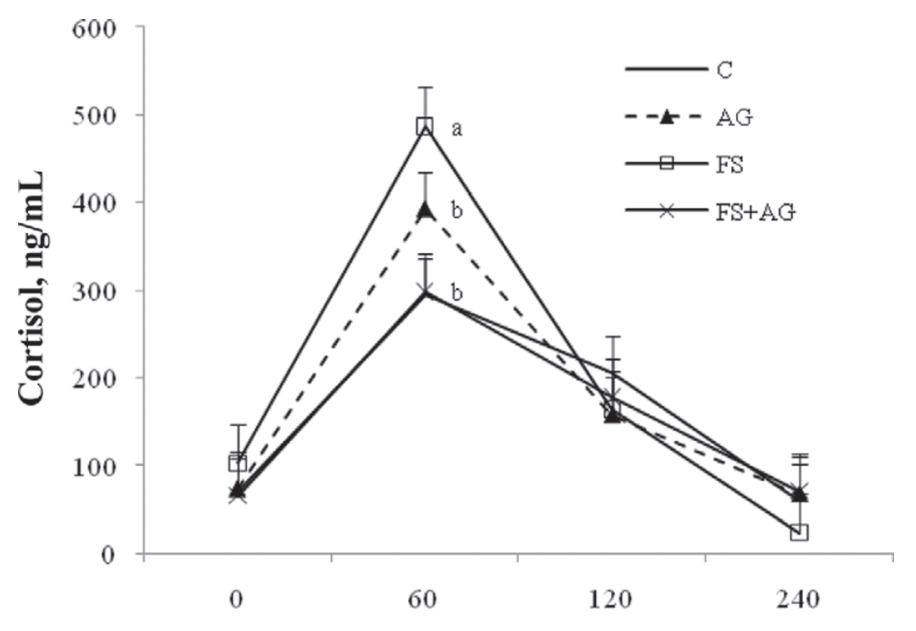

Time after ACTH challenge, min

Figure 3. Plasma cortisol production (LSM \pm SEM) measured immediately before and then at 60, 120, and $240 \mathrm{~min}$ after ACTH challenge at $22 \mathrm{~d}$ of the experiment in sheep fed control diet (C), or supplemented with Ascophyllum nodosum (AG), flaxseed (FS), or a combination of A. nodosum and flaxseed (FS+AG). ${ }^{\mathrm{a}, \mathrm{b}}$ Values with different letters differ between feeding treatments within a sampling day $(P<0.05)$.

d 15, IL-10 concentrations were greater in AG, FS, and FS+AG groups than in the control group $(P<0.05)$. Concentrations of IL- 4 in plasma samples decreased throughout the experiment in all groups $(P<0.001)$, with no differences among the groups (Figure $5 \mathrm{~b}$ ).

On average, FS+AG ewes showed lower IL-13 plasma mean concentrations than did FS, AG, and $\mathrm{C}$ ewes $(P$ $<0.05$ ). Plasma concentrations of IL-13 decreased in all groups at $30 \mathrm{~d}$ compared with earlier sampling times $(P<0.001)$. The FS+AG ewes had lower plasma concentrations of IL-13 than control and AG ewes at d 15, and lower concentrations than control, AG, and FS ewes at d $30(P<0.05$; Figure $5 \mathrm{c})$.

Plasma concentrations of IL-12 were affected by time of sampling $(P<0.001)$ and had increased in all groups by $30 \mathrm{~d}$ of the experiment. In particular, FS and FS+AG ewes had greater IL-12 concentrations than C and AG ewes at d $30(P<0.05$; Figure $5 \mathrm{~d})$. Concentrations of IFN- $\gamma$ decreased at $30 \mathrm{~d}$ in all groups $(P$ $<0.001)$. At that time, control ewes displayed greater concentrations of plasma IFN- $\gamma$ than did FS+AG ewes (Figure 5e).

\section{HSP}

Concentrations of HSP 70 in white blood cell lysate were affected by time $\times$ diet: FS ewes had lower HSP 70 concentrations at $\mathrm{d} 30$ than at $\mathrm{d} 0$ or $15(P<0.05)$. In contrast, the concentrations of HSP 70 in AG ewes were greater at $d 30$ than at the beginning of the ex- periment (Figure 6a). At d 30, FS and C ewes had greater concentrations of HSP 90 in white blood cell lysate than did FS+AG ewes $(P<0.05$; Figure $6 \mathrm{~b})$.

\section{DISCUSSION}

In this study, sheep were used as in vivo models to evaluate the effects of PUFA supplementation from different sources on HPA activation and immune regulation under heat stress conditions. The positive influence of supplementation on HPA activation and immune regulation could play a role in sustaining the altered immune response found in sheep under heat stress.

Prolonged exposure to maximum air temperature $>30^{\circ} \mathrm{C}$ and to THI $>80$ prevent lactating ewes from maintaining their thermal balance, thus inducing heat stress (Sevi et al., 2001). The meteorological conditions registered both inside and outside the experimental pens may account for the high RR observed. The RR

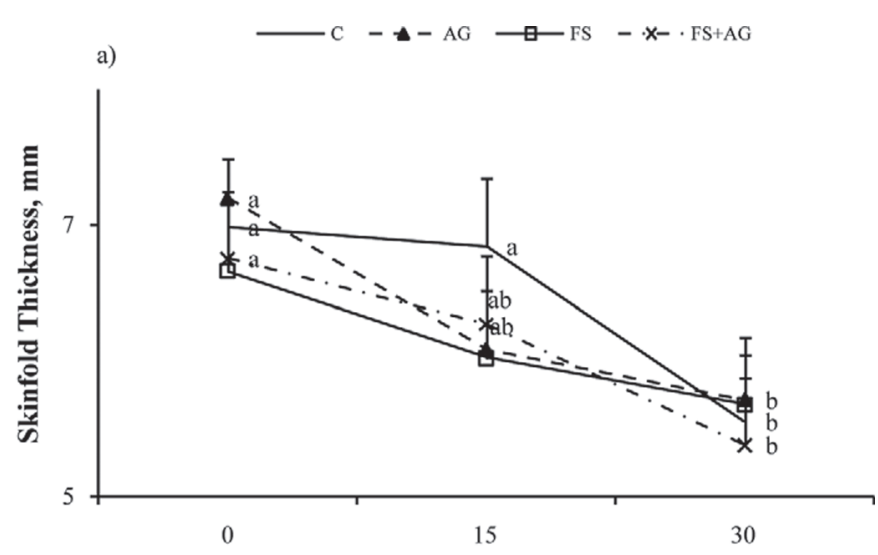

b)

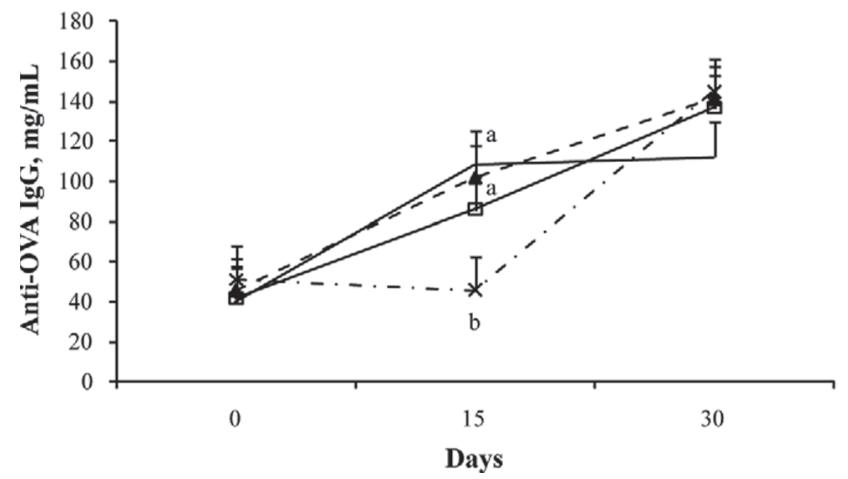

Figure 4. Least squares means \pm SEM of (a) skinfold thickness measured after phytohemagglutinin (PHA) injection at 0,15 , and 30 $\mathrm{d}$ of the experiment in sheep fed control diet $(\mathrm{C})$, or supplemented with Ascophyllum nodosum (AG), flaxseed (FS), or a combination of A. nodosum and flaxseed (FS+AG); (b) antibody titers to ovalbumin (OVA) detected in blood of sheep at 0,15 , and $30 \mathrm{~d}$ of the experiment. ${ }^{a, b}$ Values with different letters differ between feeding treatments within a sampling day $(P<0.05)$. 

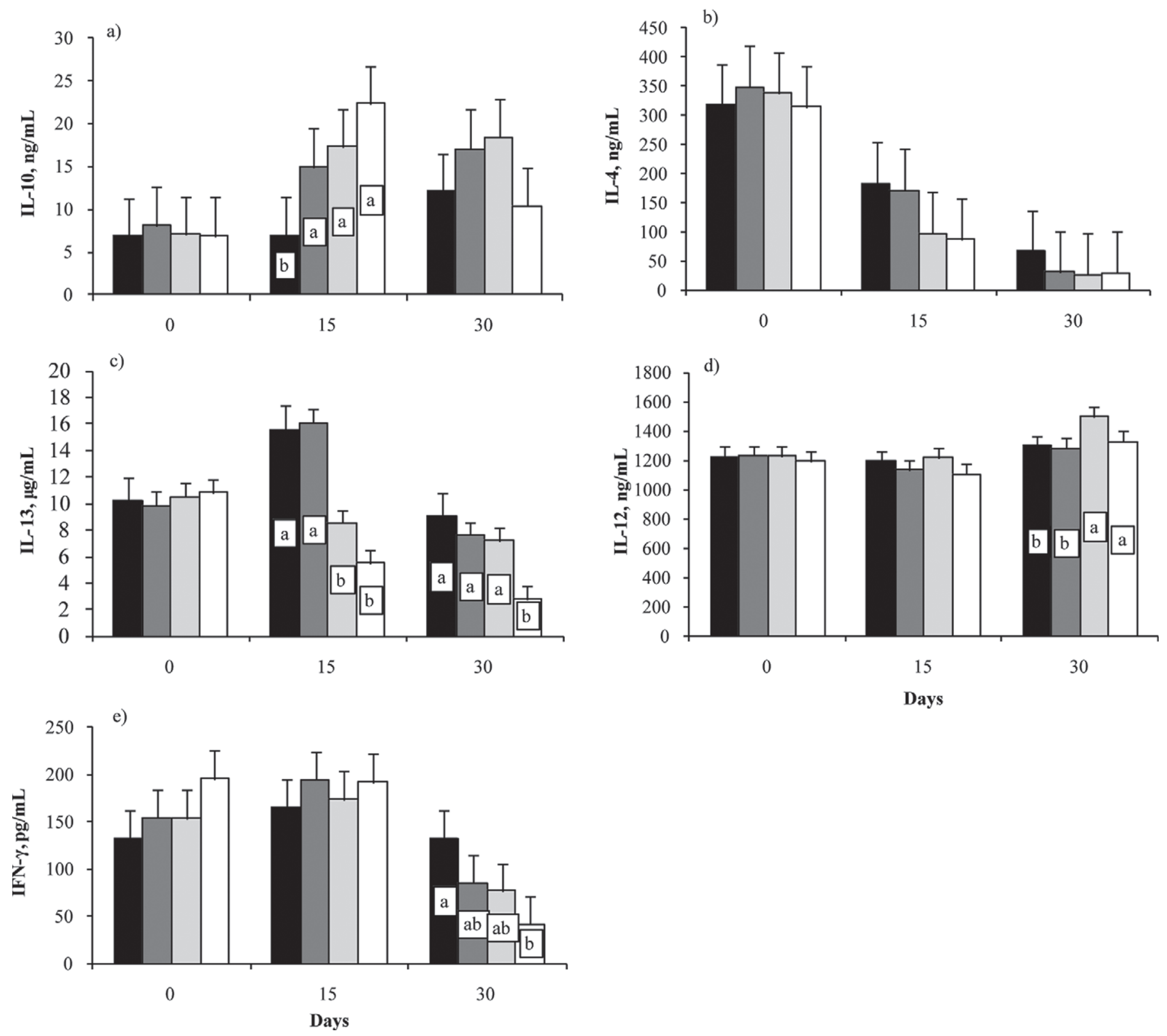

Figure 5. Least squares means \pm SEM of (a) IL-10 production; (b) IL-4 production; (c) IL-13 production; (d) IL-12 production; (e) IFN- $\gamma$ production measured at 0,15 , and $30 \mathrm{~d}$ of the experiment in plasma of sheep fed control diet (C), or supplemented with Ascophyllum nodosum (AG), flaxseed (FS), or a combination of $A$. nodosum and flaxseed (FS+AG). ${ }^{\mathrm{a}, \mathrm{b}}$ Values with different letters differ between feeding treatments within a sampling day $(P<0.05)$.

measured in ewes in the current study suggested they were under heat stress, according to Silanikove (2000), who defined a panting rate of 80 to 120 as indicative of high heat stress in farm animals. The lower RR measured in FS and FS+AG sheep compared with $\mathrm{C}$ and AG sheep confirmed previous findings on the positive peripheral vasodilator effect of flaxseed, even in combination with $A$. nodosum, in helping sheep to cope with heat stress (Caroprese et al., 2012). However, it should be noted that administration of flaxseed in the diet slightly reduced the DMI of ewes.

Acute heat stress can act on HPA axis activation by increasing plasma cortisol secretions to increase glucose availability and meet the enhancement of energy demand for thermoregulation (Matteri et al., 2000). In ruminants, diet can also influence activation of the 
a)

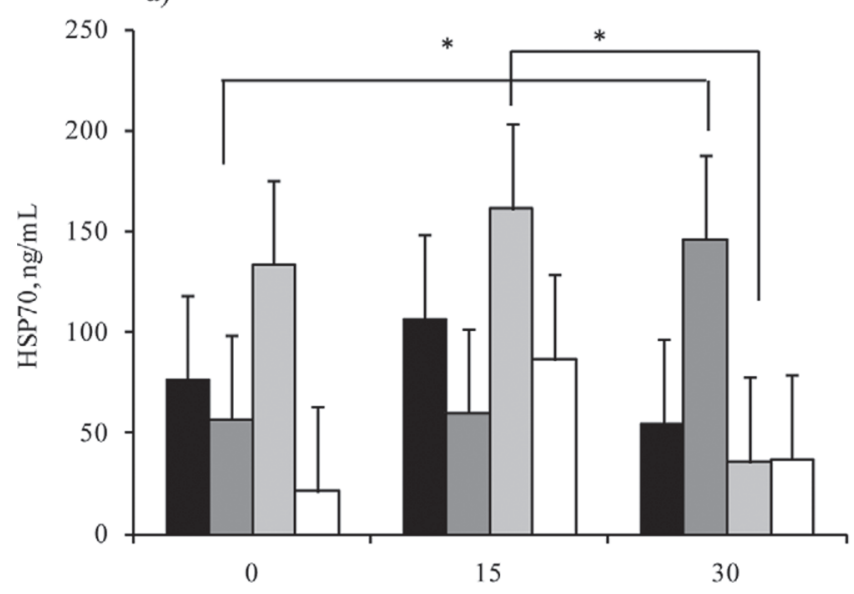

b)

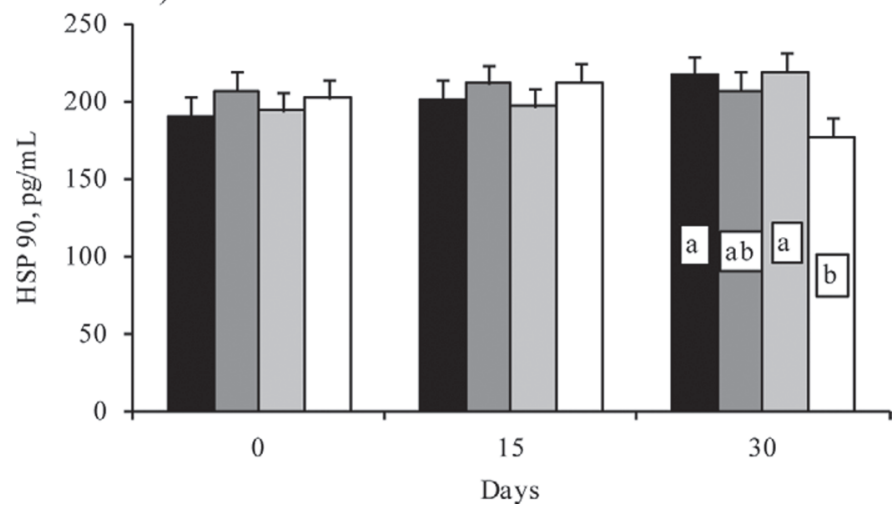

Figure 6. Least squares means \pm SEM of (a) heat-shock protein 70 (HSP70) concentration measured at 0,15 , and $30 \mathrm{~d}$ of the experiment in white blood cells lysate of sheep fed control diet (C), or supplemented with Ascophyllum nodosum (AG), flaxseed (FS), or a combination of $A$. nodosum and flaxseed (FS+AG). *Shows a significant difference between different sampling days within feeding treatments $(P<0.05)$; (b) HSP90 concentration measured at 0,15 , and $30 \mathrm{~d}$ of the experiment in white blood cells lysate of sheep fed the treatment diets. ${ }^{\mathrm{a}, \mathrm{b}}$ Values with different letters differ between feeding treatments within a sampling day $(P<0.05)$.

HPA axis and expression of genes involved in the stress response, as stated in several studies (Munksgaard et al., 2006; Stefanon et al., 2009; Sgorlon et al., 2012). The increase of cortisol secretion in ewes under heat stress and supplemented with flaxseed, as found in our experiment, was in agreement with a previous study (Caroprese et al., 2012), and demonstrated the ability of flaxseed supplementation to interfere with cortisol secretion. On the other hand, the reduced cortisol secretions in sheep in the FS+AG group compared with cortisol secretions of FS sheep might support the hypothesis of the existence of a negative synergy of flaxseed and algae as regards HPA activation.

Hyperthermia and the consequent increase in cortisol secretion can suppress cell-mediated immunity, down- regulating Th1 cytokines in favor of the secretion of Th2 cytokines (Murzenok et al., 1997; Elenkov and Chrousos, 1999; Webster et al., 2002). The Th2 cells mainly produce IL-4, IL-13, and IL-10, which are able to sustain humoral immunity; IL-4 and IL-10 stimulate the differentiation of $\mathrm{B}$ cells into antibody-secreting $\mathrm{B}$ cells, and can inhibit macrophage activation, proinflammatory cytokine production, and T-cell proliferation. Interleukin-10 is produced by $\mathrm{T}$ lymphocytes, $\mathrm{B}$ cells, eosinophils, mast cells, and monocytes (Asadullah et al., 2003) and is considered the key antagonist of Th1 response by regulating cytokine production and acting on posttranscriptional mechanisms (Moore et al., 2001). Flaxseed supplementation in heat-stressed dairy cows resulted in a reduction of IL-10 production and in an enhanced cellular immune response, supporting the hypothesis that whole flaxseed was able to modulate immune responses of cows under heat stress by opposing the shift of lymphocytes from Th1 to Th2 type that usually occurs under heat stress conditions (Caroprese et al., 2009). In the present study, the cell-mediated immune response decreased in all the experimental groups with the exception of the FS group, probably as a result of downregulation of Th1 responses exerted by heat stress. Diet supplementation administrated under heat stress conditions could have different effects on the regulation of immune responses based on the extent of heat stress and according to species differences. The increased plasma concentrations of IL-10 in the experimental groups compared with the control group confirmed a possible role of diet in regulating immune responses, probably by altering the expression of different genes involved in the stress response. Furthermore, glucocorticoids have a direct effect on IL-10 production because they are able to upregulate IL-10 secretion by T cells (Elenkov and Chrousos, 1999). Ewes fed flaxseed had increased cortisol concentrations compared with all the other groups, which could have deeply influenced their production of IL-10. The increased IL-10 secretions in FS ewes could explain the absence of the expected direct positive effect of flaxseed supplementation on the cellular immune response, as found in cows. In a previous study in heat-stressed ewes, the increase in cortisol secretion was responsible for the impairment of their cellular immune response after intradermal injection of mitogens (Sevi et al., 2002). In the present experiment, FS ewes, despite the increased cortisol and IL-10 concentrations, showed stable and durable cellular immune responses, according to previous studies in cows (Caroprese et al., 2009). The increase in IL-10 production registered in all experimental groups at $\mathrm{d} 15$ might have a direct suppressive effect on the Th1 cell response by reducing the secretion of IFN- $\gamma$ (Elenkov and Chrousos, 1999). The reduction of IFN- $\gamma$ concen- 
trations observed in AG+FS ewes at $30 \mathrm{~d}$ could be the direct result of the high IL-10 production measured in this group. On the other hand, IL-12 is known to be a critical factor for cell-mediated immune response in vitro, stimulating IFN- $\gamma$ production (Macatonia et al., 1993; Brown and Estes, 1997). Interleukin-12, which is produced by monocytes, dendritic cells, and neutrophils, can alter the balance between Th1 and Th2 responses by enhancing cell-mediated immune responses and impairing the production of immunoglobulins involved in Th2 humoral responses. Brown and Estes (1997) reported that IL-12 increased IFN- $\gamma$ production in bovine peripheral blood mononuclear cells (PBMC) after mitogen or parasite antigen stimulation. In the present experiment, FS ewes had IFN- $\gamma$ concentrations similar to those found in control ewes, despite the increased concentrations of both plasma IL-10 and glucocorticoids observed. The increased concentrations of plasma IL-12 detected in FS ewes at the end of the experiment could be, at least partly, responsible for IFN- $\gamma$ production and cell-mediated immune responses of FS ewes at the end of the trial. In mitogen-activated ovine PBMC, the addition of recombinant ovine IL-12 enhances IFN- $\gamma$ production and has a small effect on cell proliferation. In contrast, recombinant ovine IL-10 has a great inhibiting effect on cell proliferation and a small negative effect on IFN- $\gamma$ production; no consistent relationship between IL-10 and IFN- $\gamma$ production was found (Wattegedera et al., 2004). Previous findings from the studies on IL-10, IL-12, and IFN- $\gamma$ in in vitro experiments seem to be consistent with the findings of our in vivo experiment. Our results confirmed the complexity of the cross-talk between IL-10 and IL-12 and the importance of a balance of cytokine profile in controlling the in vivo Th1 and Th2 responses in sheep in terms of cell-mediated and humoral immune responses. Based on our data, it could be argued that whole flaxseed supplementation contributed to sustain Th1 response in ewes subjected to heat stress.

Both IL-4 and IL-13 play an important role in the regulation of Th2 cells and in the development of humoral immune responses, even if IL-13, differently from IL-4, cannot stimulate the growth of activated T cells (Zurawski and de Vries, 1994). Based on these findings, the lowest IL-13 plasma concentrations found in FS+AG ewes could explain the trend of anti-OVA $\mathrm{IgG}$ production in $\mathrm{FS}+\mathrm{AG}$ ewes at d 15. In humans, the expression and production of IL-13 was more rapid and longer lasting than the expression and production of IL-4 in T cells stimulated with concanavalin A; in addition, a dose- and time-dependent increase in IL-13 production in PBMC stimulated with PHA was observed (de Waal Malefyt at al., 1995; Luttmann et al., 1999). Luttmann et al. (1999), based on the different kinetics of IL-4 and IL-13 production, suggested that IL-4 could be restricted to the first phases of an initiated Th2 immune response, whereas IL-13 could play a role in the ongoing immune response. In IL-4-deficient mice, IL-13 transgene expression did not reverse $\operatorname{IgG}_{1}$ deficiency, suggesting a marginal role for IL-13 in regulating production of $\mathrm{IgG}_{1}$ (McKenzie et al., 1998). The immunological responses in FS+AG sheep seem to suggest a negative synergistic effect of n-3 PUFA from flaxseed (mainly C18:3) and from A. nodosum (mainly EPA), when administered in combination, in influencing immune activation in sheep under heat stress. A reduction in Th1 (by decreasing IFN- $\gamma$ production) and Th2 (by decreasing production of anti-OVA IgG and IL-13) responses was indeed observed.

Sheep can synthesize HSP 70 and HSP 90 in vitro; however, differences in the synthesis of HSP in different livestock species have been demonstrated (Guerriero and Raynes, 1990). On the cell surface of monocyte-derived dendritic cells, which contain high concentrations of proinflammatory cytokines, very high concentrations of inducible-HSP 70 in hyperthermic stress was found (Oosterveld and Rasker, 1994). Heat stress and IL-13 can amplify the production of inducible HSP 70 (Martin et al., 2009). As a consequence, the increase of IL-13 in $\mathrm{AG}$ ewes at d 15 could justify the increase of in vivo HSP 70 production in AG ewes at d 30. Analogously, the reduction of IL-13 in FS ewes measured at d 15 could explain, at least in part, the reduction in the concentrations of plasma HSP 70 in FS ewes measured at $30 \mathrm{~d}$ of the experiment. Heat shock protein $70 \mathrm{can}$ induce production of IL-10 (Wendling et al., 2000), suggesting a possible role for HSP 70 in increasing plasma concentrations of IL-10 in FS ewes at d 15. Plasma concentrations of HSP 90 in FS ewes can be explained by the increased IL-10 concentrations measured in FS ewes at d 15. Interleukin-10 can upregulate gene expression of HSP 90 in PBMC and in a human hepatoma cell line (Hep G2), activating the HSP 903 gene promoter and increasing HSP 90 concentrations (Ripley et al., 1999). Nevertheless, given the greater cortisol secretion observed in FS group compared with other groups, a role of cortisol on HSP 90 plasma concentrations cannot be excluded.

\section{CONCLUSIONS}

Findings from this experiment confirm a role for flaxseed supplementation in helping sheep cope with heat stress. Polyunsaturated fatty acids from flaxseed elicited activation of the HPA axis by enhancing cortisol secretion, probably to meet increased energy demand for thermoregulation. In addition, supplementation of flaxseed in the diet helped to sustain Th1 responses, 
in terms of in vivo cell-mediated immune response to PHA, by complex cross-talk between IL-10, IL-12, and IFN- $\gamma$. In sheep supplemented with flaxseed, the reduced concentrations of IL-13 were connected to the reduction of HSP 70, and the increased concentrations of IL-10 were related to the increase in HSP 90. Supplementation of the diet with $A$. nodosum did not lead to an enforcement of cell-mediated and humoral responses or an alteration in HPA axis activation but did result in increased concentrations of HSP 70 . The combined supplementation of flaxseed and A. nodosum to sheep under heat stress appeared to influence immune responses with a reduction of both Th1 (by decreasing IFN- $\gamma$ production) and Th2 responses (by decreasing anti-OVA IgG and IL-13 production), suggesting a synergistic negative effect of n-3 PUFA from flaxseed, mainly C18:3, and from A. nodosum, mainly EPA.

\section{ACKNOWLEDGMENTS}

The authors thank Claire Moore (University of Foggia, Foggia, Italy) for English revision.

\section{REFERENCES}

AOAC (Association of Official Analytical Chemists). 1990. Official Methods of Analysis. 15th ed. AOAC, Arlington, VA.

Asadullah, K., W. Sterry, and H. D. Volk. 2003. Interleukin-10 therapy-Review of a new approach. Pharmacol. Rev. 55:241-269.

Begg, D. J., R. O'Brien, C. G. Mackintosh, and J. F. Griffin. 2005. Experimental infection model for Johne's disease in sheep. Infect. Immun. 73:5603-5611.

Brown, W. C., and D. M. Estes. 1997. Type 1 and type 2 responses in cattle and their regulation. Pages 15-33 in Cytokines in Veterinary Medicine. V. E. C. J. Shijns and M. C. Horzinek, ed. CAB International, Wallingford, UK.

Caroprese, M., M. Albenzio, A. Bruno, G. Annichiarico, R. Marino, and A. Sevi. 2012. Effects of shade and flaxseed supplementation on welfare of lactating ewes under high ambient temperatures. Small Rumin. Res. 102:177-185.

Caroprese, M., M. Albenzio, A. Bruno, V. Fedele, A. Santillo, and A. Sevi. 2011. Effect of solar radiation and flaxseed supplementation on milk production and fatty acid profile of lactating ewes under high ambient temperature. J. Dairy Sci. 94:3856-3867.

Caroprese, M., A. Marzano, G. Entrican, S. Wattegedera, M. Albenzio, and A. Sevi. 2009. Immune response of cows fed polyunsaturated fatty acids under high ambient temperatures. J. Dairy Sci. 92:2796-2803.

Collier, R. J., J. L. Collier, R. P. Rhoads, and L. H. Baumgard. 2008. Invited review: Genes involved in the bovine heat stress response. J. Dairy Sci. 91:445-454.

de Waal Malefyt, R., J. S. Abrams, S. M. Zurawski, J. C. Lecron, S. Mohan-Peterson, B. Sanjanwala, B. Bennet, J. Silver, J. E. de Vries, and H. Yssel. 1995. Differential regulation of IL-13 and IL-4 production by human CD $8+$ and CD4+ Th0, Th1 and Th2 T cell clones and EBV-transformed B cells. Int. Immunol. 7:1405-1416.

European Union. 2010. EU Directive 2010/63/EU of 22 September 2010 on the protection of animals used for scientific purposes. Off. J. Eur. Commun. L276:33-79.

Elenkov, I. J., and G. P. Chrousos. 1999. Stress hormones, Th1/Th2 patterns, pro/anti-inflammatory cytokines and susceptibility to disease. Trends Endocrinol. Metab. 10:359-368.
Eulitz, K., M. P. Yurawecz, N. Sehat, J. Fritsche, J. A. G. Roach, M. M. Mossoba, J. K. G. Kramer, R. O. Adlof, and Y. Ku. 1999. Preparation, separation, and confirmation of eight geometrical cis/trans conjugated linoleic acid isomers 8,10- through 11,13-18:2. Lipids 34:873-877.

Guerriero, V. Jr., and D. A. Raynes. 1990. Synthesis of heat stress proteins in lymphocytes form livestock. J. Anim. Sci. 68:2779-2783.

Hope, J. C., L. S. Kwong, G. Entrican, S. Wattegedera, H. M. Vordermeier, P. Sopp, and C. J. Howard. 2002. Development of detection methods for ruminant interleukin (IL)-12. J. Immunol. Methods 266:117-126.

Kelly, C. F., and T. E. Bond. 1971. Bioclimatic Factors and Their Measurement: A Guide to Environmental Research on Animals. Natl. Acad. Sci., Washington, DC.

Kwong, L. S., J. C. Hope, M. L. Thom, P. Sopp, S. Duggan, G. P. Bembridge, and C. J. Howard. 2002. Development of an ELISA for bovine IL-10. Vet. Immunol. Immunopathol. 85:213-223.

Luttmann, W., C. Sengler, V. Herzog, S. Balkow, H. Mathys, and J. C. Virchow Jr. 1999. Differential modulation of inteleukin-4 and interleukin-13 secretion from human peripheral blood mononuclear cells. Immunol. Lett. 69:225-231.

Macatonia, S. E., C. S. Hsieh, K. M. Murphy, and A. O'Garra. 1993. Dendritic cells and macrophages are required for Th1 development of $\mathrm{CD}^{+}$cells from $\alpha \beta$ TCR transgenic mice: IL-12 substitution for macrophages to stimulate IFN $\gamma$ production is IFN- $\gamma$ dependent. Int. Immunol. 5:1119-1128.

Martin, C. A., D. L. Kurkowski, A. M. Valentino, and F. SantiagoSchwarz. 2009. Increased intracellular, cell surface, and secreted inducible heat shock protein 70 responses are triggered during the monocyte to dendritic cell (DC) transition by cytokines independently of heat stress and infection and may positively regulate DC growth. J. Immunol. 183:388-399.

Matteri, R. L., J. A. Carroll, and C. J. Dyer. 2000. Neuroendocrine responses to stress. Pages 43-76 in The Biology of Animal Stress. K. Sejrsen, T. Hvelplund, and M. O. Nielsen, ed. CABI Publishing, Wallingford, UK.

McKenzie, G. J., C. L. Emson, S. E. Bell, S. Anderson, P. Fallon, G. Zurawski, R. Murray, and A. N. J. McKenzie. 1998. Impaired development of Th2 cells in IL-13-deficient mice. Immunity 9:423432.

Moore, K. W., M. R. de Waal, R. L. Coffman, and A. O'Garra. 2001. Interleukin-10 and the interleukin-10 receptor. Annu. Rev. Immunol. 19:683-765.

Munksgaard, L., M. S. Herskin, P. Løvendahl, and J. B. Andersen. 2006. Effects of nutrition on stress reactivity. Pages 511-525 in Ruminant Physiology. K. Sejrsen, T. Hvelplund, and M. O. Nielsen, ed. Wageningen Academic Publishers, Wageningen, the Netherlands.

Murzenok, P. P., N. I. Netukova, and T. I. Zhytkevitch. 1997. Ultrastructure and functional state of rabbit lymphoid cells after repeated exposure to lipopolysaccharide and external heating. Arch. Immunol. Ther. Exp. (Warsz.) 45:301-305.

NRC. 2001. Nutrient Requirements of Dairy Cattle. 7th rev. ed. Natl. Acad. Sci., Washington, DC.

O'Fallon, J. V., J. R. Busboom, M. L. Nelson, and C. T. Gaskins. 2007. A direct method for fatty acid methyl ester synthesis: Application to wet meat tissues, oils, and feedstuffs. J. Anim. Sci. 85:1511-1521.

Oosterveld, F. G., and J. J. Rasker. 1994. Effect of local heat and cold treatment on surface and articular temperature of arthritic knees. Arthritis Rheum. 37:1578-1582.

Park, H. G., S. I. Han, S. Y. Oh, and H. S. Kang. 2005. Cellular responses to mild heat stress. Cell. Mol. Life Sci. 62:10-23.

Ripley, B. J. M., A. Stephanou, D. A. Isenberg, and D. S. Latchman. 1999. Interleukin-10 activates heat-shock $90 \beta$ gene expression. Immunology 97:226-231.

Ronsen, O., B. K. Pedersen, T. R. Øritsland, R. Bahr, and J. KjeldsenKragh. 2001. Leukocyte counts and lymphocyte responsiveness associated with repeated bouts of strenuous endurance exercise. J. Appl. Physiol. 91:425-434. 
Saker, K. E., J. H. Fike, H. Veit, and D. L. Ward. 2004. Brown seaweed-( Tasco $\left.^{\mathrm{TM}}\right)$ treated conserved forage enhances antioxidant status and immune function in heat-stressed wether lambs. J. Anim. Physiol. Anim. Nutr. 88:122-130.

Sevi, A., M. Albenzio, G. Annicchiarico, M. Caroprese, R. Marino, and L. Taibi. 2002. Effects of ventilation regimen on the welfare and performance of lactating ewes in summer. J. Anim. Sci. 80:2349 2361.

Sevi, A., G. Annicchiarico, M. Albenzio, L. Taibi, A. Muscio, and S. Dell'Aquila. 2001. Effects of solar radiation and feeding time on behavior, immune response and production of lactating ewes under high ambient temperature. J. Dairy Sci. 84:629-640.

Sgorlon, S., M. Colitti, E. Asquini, A. Ferrarini, A. Pallavicini, and B. Stefanon. 2012. Administration of botanicals with the diet regulates gene expression in peripheral blood cells of Sarda sheep during ACTH challenge. Domest. Anim. Endocrinol. 43:213-226.

Shapiro, S. S., and M. B. Wilk. 1965. An analysis of variance test for normality. Biometrika 52:591-601.

Silanikove, N. 2000. Effects of heat stress on the welfare of extensively managed domestic ruminants. Livest. Prod. Sci. 67:1-18.
Stefanon, B., S. Sgorlon, G. De Moro, and E. Asquini. 2009. Action of larch bark in the regulation of cortisol induced stress in sheep. Ital. J. Anim. Sci. 8:162-164.

Wattegedera, S., K. Sills, C. J. Howard, J. C. Hope, C. J. McInnes, and G. Entrican. 2004. Variability in cytokine production and cell proliferation by mitogen-activate ovine peripheral blood mononuclear cells: Modulation by interleukin (IL)-10 and IL-12. Vet. Immunol. Immunopathol. 102:67-76.

Webster, J. I., L. Tonelli, and E. M. Sternberg. 2002. Neuroendocrine regulation of immunity. Annu. Rev. Immunol. 20:125-163.

Wendling, U., L. Paul, R. van der Zee, B. Prakken, M. Singh, and W. A. van Eden. 2000. Conserved mycobacterial heat shock protein (hsp) 70 sequence prevents adjuvant arthritis upon nasal administration and induces IL-10 producing T cells that cross-react with the mammalian self-hsp70 homologue. J. Immunol. 164:27112717.

Zurawski, G., and J. E. de Vries. 1994. Interleukin-13, an interleukin-4 like cytokine that acts on monocytes and B-cells, but not on $\mathrm{T}$ cells. Immunol. Today 15:19-26. 